\title{
U-PB CHRONOLOGICAL CHARACTERISTICS OF MESOPROTEROZOIC LA-ICP-MS DETRITAL ZIRCONS IN THE XIONG'ER RIFTING TROUGH AND ITS PALEOENVIRONMENT ANALYSIS
}

\author{
DAI, R. ${ }^{1}$ - ZHANG, Y. $.^{*}-$ LUO, S. S. ${ }^{1,3}-$ WANG, Z. C. ${ }^{4}$ - WANG, T. S. ${ }^{4}-$ LYU, Q. Q. ${ }^{2}-$ \\ GUAN, Y. L. ${ }^{2}$ \\ ${ }^{1}$ Laboratory of Exploration Technologies for Oil and Gas Resources of Ministry of Education \\ Yangtze University, Wuhan 430100, China \\ ${ }^{2}$ School of Geosciences, Yangtze University, Wuhan 430100, China \\ ${ }^{3}$ Hubei Cooperative Innovation Center of Unconventional Oil and Gas, Wuhan 430100, China \\ ${ }^{4}$ Research Institute of Petroleum Exploration \& Development, Beijing 100083, China \\ ${ }^{*}$ Corresponding author \\ e-mail:201671301@yangtzeu.edu.cn \\ (Received $3^{\text {rd }}$ May 2019; accepted $11^{\text {th }}$ Jul 2019)
}

\begin{abstract}
In order to understand the sedimentary age and geotectonic environment characteristics of the Ruyang Group in geological history, this study, with the LA-ICP-MS method, focuses on the study of U$\mathrm{Pb}$ isotope geochronology and geotectonic environment analysis of detrital zircons in the bottom of Xiaogoubei Formation of Ruyang Group in Daimeishan of Henan. Results show that the ages of detrital zircons of Xiaogoubei Formation range from $1720 \mathrm{Ma}$ to $2727 \mathrm{Ma}$, the youngest detrital zircon age near the harmonic line is $1720 \pm 65 \mathrm{Ma}$, the main peak age is $2547 \mathrm{Ma}$, and the second peak ages include $2178 \mathrm{Ma}$ and $1832 \mathrm{Ma}$. Therefore, we consider that the lower age limit of Xiaogoubei Formation is $\sim 1720 \mathrm{Ma}$; the sediment sources of Xiaogoubei Formation mainly come from the geological bodies of the interior of the North China craton in the late Neoarchean, early Paleoproterozoic, middle Paleoproterozoic, late Paleoproterozoic and early Neoproterozoic. At the same time, the detrital zircon age of samples has a good response relationship with the Precambrian geological events in North China Craton, which reveals the then construction environment.
\end{abstract}

Keywords: zircon LA-ICP-MS U-Pb dating, xiaogoubei formation, changchengian system, xiong'er rift trough, North China Craton

\section{Introduction}

There are many opinions on the division of the stratigraphic ages of Xiong'er rift trough: Guan et al. (1980) and Xing et al. (1996) advocated that the Ruyang Group composed of Bingmagou Formation and Beidajian Formation should be classified into the Mesoproterozoic Jixian System and the Luoyu Group composed of the Cuizhuang Formation and the Luoyukou Formation into the New Proterozoic Qingbaikou System. Chen et al. (1999) called the Bingmagou Formation - Luoyukou Formation collectively the "Ruyang Group", unifying into the Mesoproterozoic Jixian System. In order to limit the stratigraphic age, Guan et al. (1980) first obtained glauconite K-Ar dating data in the Sanjiaotang Formation and Cuizhuang Formation, i.e., $1071 \mathrm{Ma}-1089 \mathrm{Ma}$ and $1138 \mathrm{Ma}-1159 \mathrm{Ma}$, respectively, which is the basis to classify Luoyu Group into Qingbaikou System; Qiao et al. (1997) obtained the $\mathrm{Pb}-\mathrm{Pb}$ age of carbonate rocks in Luoyukou Formation as $855 \pm 54 \mathrm{Ma}$; Liu et al. (1999) obtained the Rb-Sr age of clay 
minerals as $1125 \pm 3 \mathrm{Ma}$ in the Cuizhuang Formation and the Ar-Ar age as 918.8 Ma in the flints of Dongjia Formation. In recent year, Su et al. (2012) has made important progress in this area, studied the zircon U-Pb dating of the "sedimentary tuff" interbedded in the middle part of the Luoyukou Formation near Yangpo Village in Ruzhou, Henan Province, and obtained the high-precision dating date of $1611 \pm 8 \mathrm{Ma}$, which provides accurate age data for Luoyukou Formation and its underlying strata such as Luoyu Group and Ruyang Group in this area. In the same year, Hu et al. (2012) carried out U-Pb dating of LA-ICP-MS zircon in the Maanshan Formation at the bottom of the Wufoshan Group in Songshan area, found the youngest zircon age of two samples is $1732 \pm 11 \mathrm{Ma}$ and $1655 \pm 22 \mathrm{Ma}$, respectively and defined the sedimentary age of the Songshan-Jishan Formation area, believing that the sedimentary age of the Foshan Group is later than $1655 \mathrm{Ma}$; Hu et al. (2014) obtained the youngest detrital zircon age of $1744 \pm 22 \mathrm{Ma}$ at the bottom of Yunmeng Mountain, defined the detrital sedimentary age of the rift trough after the volcanic rocks of the Xiong'er Group. All of the researches are of great significance for the stratigraphic comparison and the establishment of chronostratigraphic framework in this area.

In addition, Daimeishan area is a national geological park and AAAAA scenic spot. Its unique natural environment can not be separated from the joint action of tectonic activities, rock types and climate. Among them, tectonic activities are of great significance to its later genesis. Therefore, the analysis of tectonic environment in its geological and historical period is conducive to strengthening the understanding of its modern geographical environment. We can also understand the tectonic background and the characteristics of the surrounding environment and the large paleogeographic pattern in the western part of Henan Province of the North China Craton at that time.

This study involves the U-Pb dating of the LA-ICP-MS detrital zircon of Xiaogoubei Formation of Ruyang Group in Daimei Mountain, Henan Province. Combining the results of previous researches, this study compares the zircon ages of different regions in the southern margin of the North China Craton, and reveals the characteristics of the formation and evolution of the crystalline basement and the Xiong'er rift trough in the southern margin of the North China Craton. It is of great significance to understand the tectonic environment of the study area and restore the characteristics of paleoenvironment.

\section{Materials and methods}

\section{Regional geological background}

Xiong'er rift trough is mainly distributed in the junction of Henan, Shanxi and Shaanxi provinces in China (Figure 1a), particularly in the west of Henan, and the Neoproterozoic strata are mainly composed of neutral+acidic volcanic basement with an extremely thick $(7000 \mathrm{~m})$ of Xiong'er Group, upper detrital rock and carbonate sedimentary caprocks. The Neoproterozoic strata are divided into the XiaoqinlingLuanchuan stratigraphic block (I), the Mianchi-Qushan stratigraphic block (II), and the Songshan-Jishan stratigraphic block (III) according to the lithological combination and sedimentary characteristics of the area (Figure $1 b$ ). 


\section{Profile and sampling location}

The section of this study is located in the area of Daimei Mountain $\left(35^{\circ} 2^{\prime} 1.72^{\prime \prime} \mathrm{N}\right.$, $\left.111^{\circ} 57^{\prime} 44.26 " E\right)$, Xin'an County, Luoyang City, Henan Province (Figure 1b). The Xiaogoubei Formation and Yunmenshan Formation are observed and measured in detail in the early stage. Xiaogoubei Formation $(73.0 \mathrm{~m}$ thick) is not integrated on the metamorphic rocks of Majiahe Formation of Xiong'er Group, mainly composed of gray-grayish white medium-thick layers containing gravel sandstone and purplish red medium-fine feldspar quartz sandstone, with large-scale cross-bedding and lenticular bedding, and parallel bedding, and is of fan-delta deposit. Samples used for zircon dating are taken from the first layer of brown-yellow thick-bedded quartzite-fine medium-grained feldspar quartz sandstone (palimpsest structure can be seen) (Figure 2).

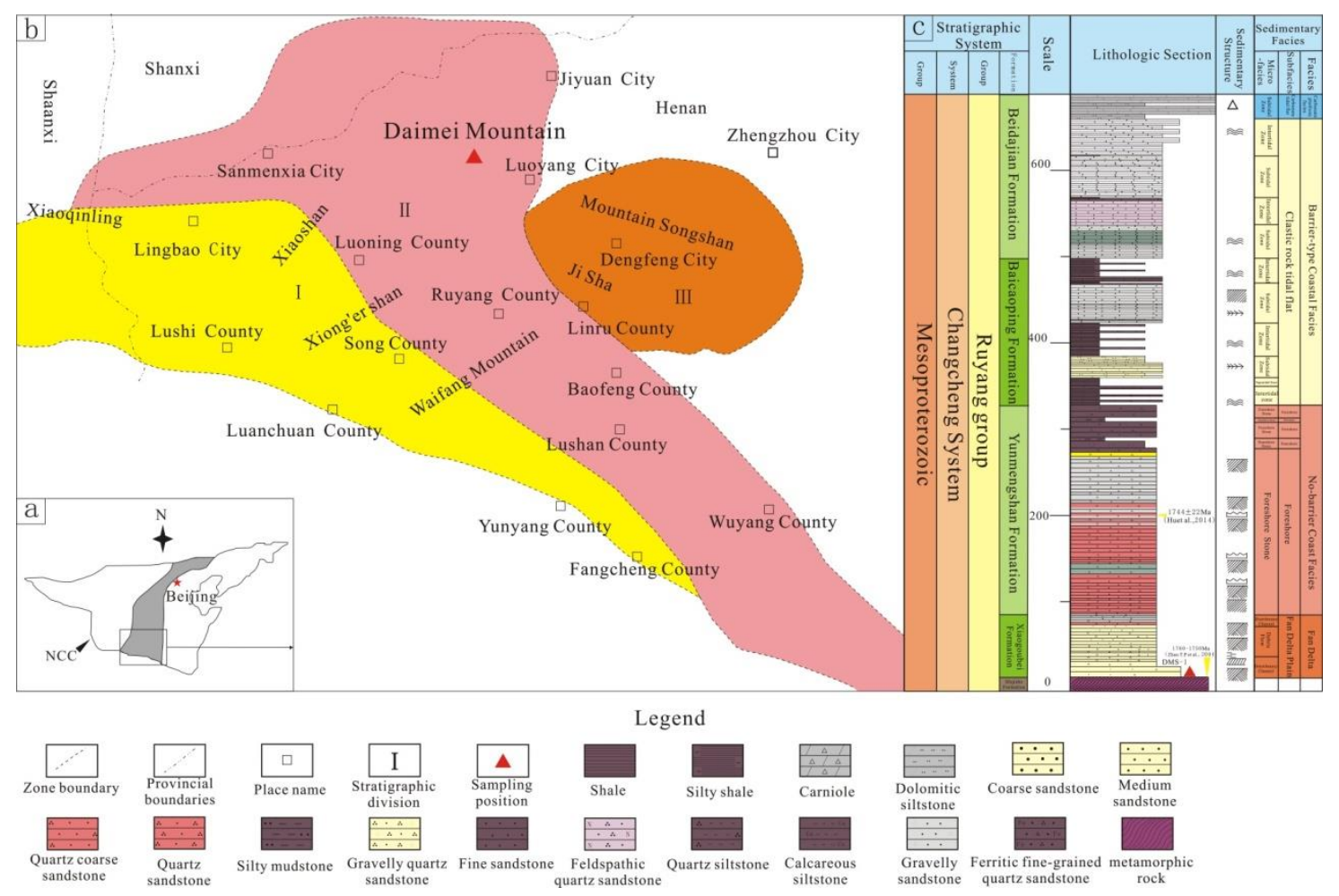

Figure 1. Geotectonic setting (a), stratigraphic zoning map (b) and sampling location map (c) of the Xiong'er rift trough (as modified by Su et al. (2012))

\section{Methods of analysis and data processing}

Sample crushing and zircon selection are completed by Langfang Keda Rock and Mineral Separation Technology Co., Ltd. By means of flotation and electromagnetic separation, single-grain zircons with different crystal shapes and sizes are selected under binocular lens to ensure their representativeness.

In general, the ${ }^{206} \mathrm{~Pb} /{ }^{238} \mathrm{U}$ age is generally used for younger zircons of less than $1000 \mathrm{Ma}$, whereas the ${ }^{207} \mathrm{~Pb} /{ }^{206} \mathrm{~Pb}$ age, which is more reliable, is generally used for older zircons of greater than $1000 \mathrm{Ma}$ due to lead loss (Black et al., 2003). After the experiment, ICPMSDataCal software (Liu et al., 2009) and Isoplot program (Ludwig, 2003) (Version 3.0) are used to analyze and process the data with the weighted average age calculated and a harmonic graph plotted. 

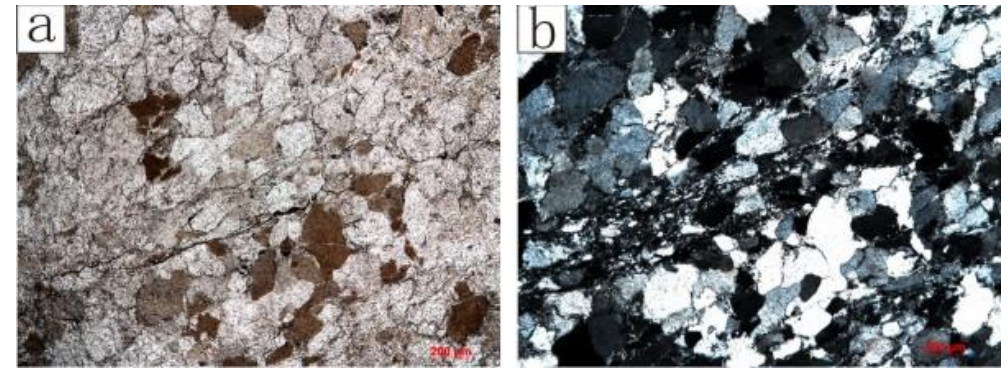

Figure 2. Photos of Xiaogoubei Formation (DMS-1) in Daimei Mountain Area, Henan Province.

Note: Fine medium-grained feldspar quartz sandstone can be seen as secondary enlargement with obvious cataclasite phenomenon. It seems to have carbon-filled micro-fissure and argillaceous complex-base filling. Photos under the thin slice of Xiaogoubei Formation

(DMS(Daimeishan)-1), single polarization (a), and orthogonal polarized light (b)

\section{Results}

\section{Morphology and $T h / U$ ratio of zircons}

Among samples, the size of zircon particles is different and mainly in the shape of equiaxial shape, followed by long column and spindle shape, with the particle diameter between 50-150 $\mu \mathrm{m}$. The grinding circle is mainly sub-circular and sub-angular with occasional round grains, so it can be seen that the zircons in the samples may come from a distant source region and have been subject to long-time handling and strong abrasion.

The cathodoluminescence image analysis shows that there are obvious differences in the internal characteristics of zircons in the samples, most of the zircons have obvious magmatic growth oscillation zonal structure, and most of the crystal zoning is narrow, indicating that the magmatic rocks are more acidic (Figure 3). The core-mantle structure can be seen in individual zircons.

\section{U-Pb age}

A total of 86 valid data points are obtained from the Xiaogoubei Formation (sample DMS-1), and the harmonic degree of its surface age is greater than 90 on average. A harmonic graph and a histogram of age distribution are made for the valid data of the samples, and most of the data points are distributed along and near the harmonic line (Figure 4). As the average age of zircons measured is more than $1000 \mathrm{Ma},{ }^{207} \mathrm{~Pb} /{ }^{206} \mathrm{~Pb}$ is selected as the age of zircon formation. The zircon age of Xiaogoubei Formation (sample DMS-1) is 1720 2727 Ma, and the youngest detrital zircons near the harmonic line is $1720 \pm 60 \mathrm{Ma}$ (measuring point DMS-1-03). The main peak age is $2547 \mathrm{Ma}$, and the second peak ages are $2178 \mathrm{Ma}$ and $1832 \mathrm{Ma}$ (Figure 4).

\section{Discussion}

\section{Restriction of harmonic age of the youngest detrital zircons on the age of Xiaogoubei Formation}

The youngest age data obtained for the detrital zircons in the sedimentary rocks will provide the largest age for the sediments, provided the samples are not contaminated 
and the test system is stable. The minimum harmonic age of detrital zircons from Xiaogoubei Formation studied in this paper is $1720 \pm 60 \mathrm{Ma}$ (measuring point DMS-103), which represents the largest sedimentary age of Xiaogoubei Formation. The topboundary age of Ruyang Group-Luoyu Group is limited to $1.6 \mathrm{Ga}$, and the bottomboundary age is limited to $1.75 \mathrm{Ga}$. In combination with the result of dating, it is shown that between $1750 \mathrm{Ma}$ and $1720 \mathrm{Ma}$, or showing a deposition discontinuity. However, due to the lack of more accurate tuff age data, this conjecture needs to be further verified.
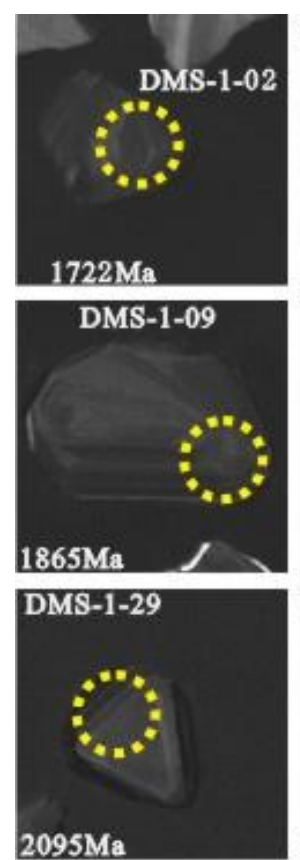

$2095 \mathrm{Ma}$
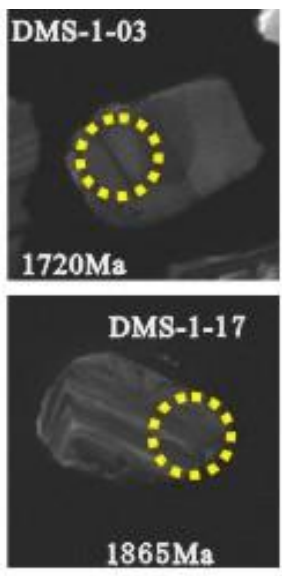

DMS-1-35

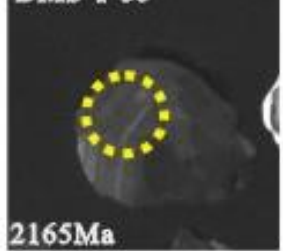

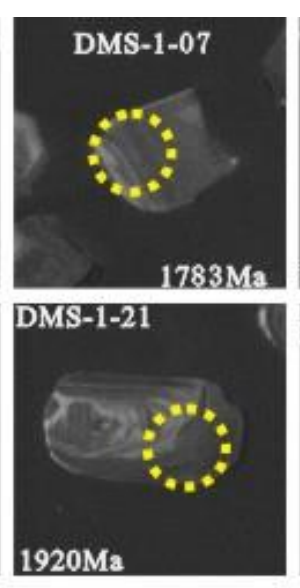
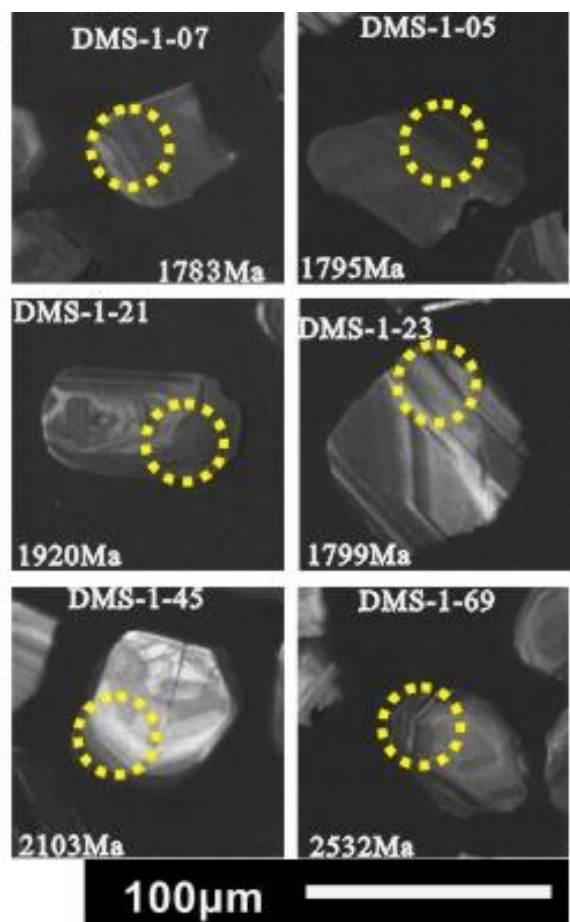

Figure 3. Xiaogoubei Formation (DMS-1) in Daimei Mountain Area, Henan Province, representative zircon cathodoluminescence (CL) image (beam spot diameter of $24 \mu \mathrm{m}$ )

\section{Source analysis of detrital zircons}

According to the analysis of zircon age distribution histogram, the age distribution of Xiaogoubei Formation is divided into three groups: 2.75 2.4 Ga (peak value is $2547 \mathrm{Ma}$ ), 2.4 2.0 Ga (peak value is $2178 \mathrm{Ma}$ ), and 2.0 1.7 Ga (peak value is $1832 \mathrm{Ma}$ ), which accounts for $34 \%, 37 \%$ and $29 \%$ of the entire zircon age distribution respectively (Figure 4). It is considered that the source of Xiaogoubei Formation comes from the geological bodies in late Neoproterozoic, early Palaeoproterozoic, middle Palaeoproterozoic, late Paleoproterozoic and early Neoproterozoic (Wan et al., 2009; Hu et al., 2010; Zhou et al., 2011).

\section{Response of detrital zircons to the precambrian geological events in the North China Craton}

\section{Crust growth and caratization events}

The peak age of $\sim 2.5 \mathrm{Ga}$ and the age distribution of few $\sim 2.7 \mathrm{Ga}$ are recorded in the detrital zircons of the Xiaogoubei Formation. For a long time, 2.9 2.7 Ga is considered 
as a period of large-scale continental crust growth in the North China Craton. The main evidences from the rocks are greenstone belts and TTG gneiss in the western Shandong region and the TTG gneiss from Jiaodong, Hengshan, Fuping, Jidong, Zhongtiao Mountains, Henan and Inner Mongolia. In addition, the peak age of $\sim 2.7 \mathrm{Ga}$ in the Proterozoic sedimentary basins of North China can also be observed, which indicates that the rocks of 2.9 2.7 Ga are common, together with the age records of $\sim 2.7 \mathrm{Ga}$ zircons from the Xiaogoubei Formation and Yunmengshan Formation of Xiong'er rift trough. In the meantime, the gneiss, TTG and granitic gneiss in the craton have the Hf and $\mathrm{Nd}$ model age of 2.9 2.7 Ga, and the age of their formation or upwelling from the mantle is considered to be 2.9 to $2.7 \mathrm{Ga}$, which indicates that the North China Craton has a large-scale continental crust formation during this period (Jahn et al., 2008).
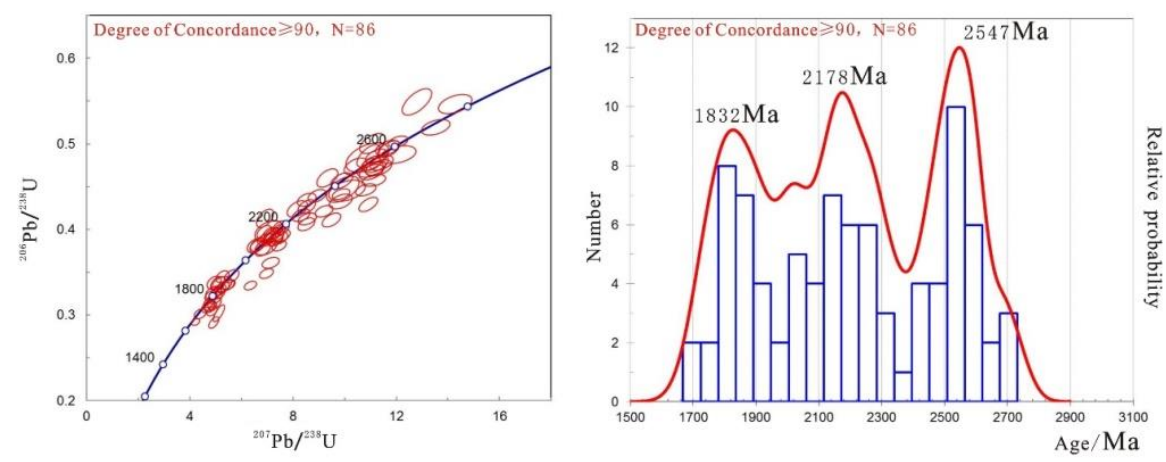

Figure 4. U-Pb harmonic curve and age distribution histogram of detrital zircons in middle Paleoproterozoic Xiaogoubei Formation (Sample DMS-1) in Daimei Mountain Area, Henan Province

\section{Paleoproterozoic rift events}

The $\mathrm{U}-\mathrm{Pb}$ age distribution of detrital zircons from Xiaogoubei Formation shows a large amount of age distribution of $2.4 \sim 1.95 \mathrm{Ga}$, with a peak value of $\sim 2.1 \mathrm{Ga}$. It is reported that during the period of 2.3 2.0 Ga, the North China Craton may have experienced a fracture-tension event of the basement continental block, and three rift belts of Fengzhen, Jiaoliao and Jinyu formed in the northern margin, eastern margin and central regions of North China, thus forming three internal sag basins (or rift belts) in Fengzhen, Jiaoliao and Jin-Henan cratons, which, along with the basic dykes, rift volcanic rocks and A-type granites found at the same time, have extensional properties, which can be proved effectively.

\section{Paleoproterozoic orogenic belt and Mesoproterozoic rift events}

In addition, the U-Pb ages of the detrital zircons in the Xiaogoubei Formation are mostly in the range of $1.95 \sim 1.7 \mathrm{Ga}$, with the peak age of $\sim 1.8 \mathrm{Ga}$. It is reported that the large-scale metamorphism of the North China Craton at 1.95 1.82 Ga and the intrusion of granite and pegmatite veins related to metamorphism may be related to $1.9 \sim 1.8 \mathrm{Ga}$ orogenic activities of three lift belts in Fengzhen, Jiaoliao and Jinyu. The zircons with the age distribution from 1.8 to $1.75 \mathrm{Ga}$ correspond to the development of the Xiong'er rift trough, accompanied by the intrusion of $1.78 \mathrm{Ga}$ basic dykes (Cui et al., 2011). This event also foreshadowed the beginning of the Mesoproterozoic rift and sedimentary events throughout the North China Craton. 


\section{Conclusions}

(1) The lower age limit of Xiaogoubei Formation is $1.72 \mathrm{Ga}$ and the Mesoproterozoic Ruyang Group is dominated by delta-clastic littoral sedimentary environment, which is obviously different from the underlying Xiong'er Group.

(2) Xiaogoubei Formation comes from the geological bodies in late Neoproterozoic, early Palaeoproterozoic, middle Palaeoproterozoic, late Paleoproterozoic and early Neoproterozoic.

(3) The detrital zircon peak age of Xiaogoubei Formation has a good response relationship with the Precambrian geological events in North China Craton: the detrital zircon age of $\sim 2.7 \mathrm{Ga}$ mainly reflects the crustal growth of the craton, the peak age of $\sim 2.5 \mathrm{Ga}$ reflects the evolution of the North China cratonization, the detrital zircon age of 2.4 1.9 Ga mainly reflects the Paleoproterozoic rift event, the detrital zircon age of $1.95 \sim 1.8 \mathrm{Ga}$ is mainly related to the orogenic activities of the three rift belts including Fengzhen, Jiaoliao and Shanxi-Henan and the detrital zircon age of 1.8 1.75 Ga mainly reflects the development period of the Xiong'er rift trough, foreshadows the beginning of the Mesoproterozoic rift event in the North China Craton.

Acknowledgements. This paper is supported by National Major Special Project of Science and Technology (2016ZX05004-001); Advanced Basic Research Project of Research Institute of Petroleum Exploration \& Development (2015yj-09).

\section{REFERENCES}

[1] Black, L. P., Kamo, S. L., Allen, C. M., Aleinikoff, J. N., Davis, D. W., Korsch, R. J., Foudoulis, C. (2003): TEMORA 1: A new zircon standard for Phanerozoic U-Pb geochronology. - Chemical Geology 200: 155-170.

[2] Chen, J. B., Gao, Z. J., Zhang. P. Y. (1999): Stratigraphic Code of ChianMesoproterozoic. - Geological Publishing House: 1-89.

[3] Cui, M. L., Zhang, B. L., Zhang, L. C. (2011): U-Pb dating of baddeleyite and zircon from the Shizhaigou diorite in the southern margin of North China craton: Constrains on the timing and tectonic setting of the Paleoproterozoic Xiong'er Group. - Gondwana Research 20(1): 184-193.

[4] Guan, B. D., Pan, Z. C., Geng, W. C. (1980): Sinian Suberathem on the North Slope of East Qinling Mountains. Sinian Suberathem In China. - Tianjin Science and Technology Press: 288-313.

[5] Hu, G. H., Hu, J. L., Chen, W., Zhao, T. P. (2010): Geochemistry and tectonic setting of the $1.78 \mathrm{Ga}$ mafic dyke swarms in the Mt.Zhongtiao and Mt.Song areas, the southern margin of the North China Craton. - Acta Petrologica Sinica 26(5): 1563-1576.

[6] Hu, G. H., Zhao, T. P., Zhou, Y. Y., Yang, Y. (2012): Depositional age and provenance of the Wufoshan Group in the southern margin of the North China Craton:Evidence from detrital zircon U-Pb ages and $\mathrm{Hf}$ isotopic compositions. - Geochimica 41(4): 326-342.

[7] Hu, G. H., Zhao, T. P., Zhou, Y. Y. (2014): Depositional age, provenance and teconic setting of the Proterozoic Ruyang Group, southern margin of the NorthChina Craton. Precambrian Research 246: 296-318.

[8] Jahn, B. M., Liu, D. Y., Wan, Y. S., Song, B., Wu, J. (2008): Archean crustal evolution of the Jiaodong Peninsula, China, as revealed by zircon SHRIMP geochronology, elemental and Nd-isotope geochemistry American. - Journal of Science 308(3): 232-269.

[9] Liu, H. Y., Hao, J., Li, Y. J. (1999): Late Precambrian Stratigraphic and Geological Evolution in Central-Eastern China. - Science Press: 1-200. 
[10] Liu, Y. S., Gao, S., Hu, Z. C., Gao, C. G., Zong, K. Q., Wang, D. B. (2009): Continental and oceanic crust recycling-induced melt-peridotite interactions in the Trans-North China Orogen: $\mathrm{U}-\mathrm{Pb}$ dating, $\mathrm{Hf}$ isotopes and trace elements in zircons from mantle xenoliths. Journal of Petrology 51(1-2): 537-571.

[11] Ludwig, K. R. (2003): User's manual for Isoplot/Ex, version3.00. A geochronological toolkit for Microsoft Excel. - Geochronology Center Special Publication 4: 1-70.

[12] Qiao, X. F., Gao, L. (1997): Carbonate Pb-Pb Isotopic Dating of Qingbaikouan System in Northern China and its Significance. - Journal of Earth Science 22(1): 1-7.

[13] Su, W. B., Li, H. K., Xu, L., Jia, S. H., Geng, J. Z., Zhou, Y. H., Wang, Z. H., Pu, H. Y. (2012): Luoyu and Ruyang Group at the South Margin of the North China Craton (NCC) Should Belong in the Mesoproterozoic Changchengian System: Direct Constraints from the LA-MC-ICPMS U-Pb Age of the Tuffite in the Luoyukou Formation, Ruzhou, Henan, China. - Geological Survey and Research 35(2): 96-108.

[14] Wan, Y. S., Liu, D. Y., Wang, S. Y., Zhao, X., Dong, C. Y., Zhou, H. Y., Yin, X. Y., Yang, C. X., Gao, L. Z. (2009): Early Precambrian Crustal Evolution in the Dengfeng Area, Henan Province (eastern China) Constraints from Geochemistry and SHRIMP UPb Zircon Dating. - Acta Geologica Sinica 83(7): 982-999.

[15] Xing, Y. S., Gao, Z. J., Wang, Z. Q. (1996): Stratigraphic Code of Chian- Neoproterozoic. - Geological Publishing House: 1-117.

[16] Zhou, Y. Y., Zhao, T. P., Wang, C. Y., Hu, G. H. (2011): Geochronology and geochemistry of 2.5 to $2.4 \mathrm{Ga}$ granitic plutons in the southern margin of the North China Craton: Implications for a tectonic transition from arc to post- collisional setting. Gondw Res 20(1): 171-183. 